\title{
ELUCIDATION OF INNATE IMMUNE COMPONENTS IN THE EPIDERMAL MUCUS OF DIFFERENT FRESHWATER FISH SPECIES
}

\author{
Kuppusamy TIMALATA ${ }^{1}$, Kasi MARIMUTHU ${ }^{*}$, Rao VENGKADES RAO ${ }^{1}$, \\ Rathinam XAVIER ${ }^{1}$, M. Aminur RAHMAN ${ }^{2}$, Subramaniam SREERAMANAN ${ }^{3}$, \\ Mariadhas Valan ARASU ${ }^{4}$, Naif Abdullah AL-DHABI ${ }^{4}$, and Jesu AROCKIARAJ ${ }^{5}$ \\ ${ }^{1}$ Department of Biotechnology, Faculty of Applied Sciences, AIMST University, Bedong, Kedah Darul Aman, Malaysia \\ ${ }^{2}$ Laboratory of Marine Biotechnology, Institute of Bioscience, Universiti Putra Malaysia, UPM Serdang, Selangor, \\ Malaysia \\ ${ }^{3}$ School of Biological Sciences, Universiti Sains Malaysia, Penang, Malaysia \\ ${ }^{4}$ Department of Botany and Microbiology, Addiriyah Chair for Environmental Studies, College of Science, King \\ Saud University, Riyadh, Saudi Arabia \\ ${ }^{5}$ Division of Fisheries Biotechnology and Molecular Biology, Department of Biotechnology, Faculty of Science and \\ Humanities, SRM University, Kattankulathur, Tamil Nadu, India
}

Timalata K., Marimuthu K., Vengkades Rao R., Xavier R., Rahman M.A., Sreeramanan S., Arasu M.V., Al-Dhabi N.A., Arockiaraj J. 2015. Elucidation of innate immune components in the epidermal mucus of different freshwater fish species. Acta Ichthyol. Piscat. 45 (3): 221-230.

Background. Fish epidermal mucus is a key component of innate immune system and plays a major role in protecting fish against invading pathogenic microbes. The information on the role of epidermal mucus components is insufficient for many commercially important freshwater fish species. Hence, this study was directed to understand the innate immune components of epidermal mucus in these fish species.

Materials and methods. Mucus samples were obtained from African catfish, Clarias gariepinus (Burchell, 1822); Indonesian snakehead, Channa micropeltes (Cuvier, 1831); striped snakehead, Channa striatus (Bloch, 1793); marble goby, Oxyeleotris marmorata (Bleeker, 1852); Nile tilapia, Oreochromis niloticus (Linnaeus, 1758); and Asian redtail catfish, Hemibagrus nemurus (Valenciennes, 1840). The variation in the protein profile of the mucus were observed using SDS-PAGE analysis. The specific activities of various hydrolytic enzymes including lysozyme, alkaline phosphatase, esterase, and protease were analysed in the mucus and the levels of enzyme activities were compared among the experimental fishes. We also elucidated the effect of various protease inhibitors on the protease activity and identified the type of proteases in the fish mucus by azocasein hydrolysis assay and zymography.

Results. Significantly $(P<0.05)$ highest levels of lysozyme-, alkaline phosphatase-, and esterase activities were observed to be $15.77,18.96$, and $10.65 \mathrm{U} \cdot \mathrm{mg}^{-1}$ protein respectively in $C$. striatus followed by $13.67,15.06$, and $16.67 \mathrm{U} \cdot \mathrm{mg}^{-1}$ protein, respectively in $C$. gariepinus. The highest level of protease activity was recorded in $H$. nemurus (1630.97 $\mathrm{U} \cdot \mathrm{mg}^{-1}$ protein) and $C$. gariepinus (1596.4 $\mathrm{U} \cdot \mathrm{mg}^{-1}$ protein). A wide range of variation was noticed in the enzyme activities of fishes, even from the same genus, for example $C$. micropeltes and $C$. striatus. Specific inhibitors were added to azocasein hydrolysis assay and zymography experiments to characterize the individual proteases present in the mucus of each fish species. This result revealed the highest level of serine proteases in mucus of redtail catfish and African catfish compared to cysteine and metalloproteases. In contrast, Indonesian snakehead and marble goby had similar levels of serine, cysteine and metalloproteases.

Conclusion. This study provides an insight into the presence of various epidermal mucus enzymes in fishes and therefore believed to be the components of innate immune system that may possibly provide protection for the fish against invading pathogenic microbes.

Keywords: fish mucus, innate immunity, enzyme activity, azocasein hydrolysis, zymography

\footnotetext{
" Correspondence: Dr. Kasi Marimuthu, Department of Biotechnology, Faculty of Applied Sciences, AIMST University, 08100 Bedong, Kedah Darul Aman, Malaysia, phone: +60-4-429 8000 (extn. 8081), fax:+60-4-429 8109, e-mail: (KT) tinapriya 87@yahoo.com,(KM) aquamuthu2k@gmail.com, (RV) vengka12@yahoo.com, (RX) rxavier77@yahoo.com, (MAR) aminur1963@gmail.com, (SS) sreeramanan@gmail.com, (MVA) mvalanarasu@gmail.com, (NAAD) naifaldhabi2014@gmail.com, (JA) jesuaraj@gmail.com.
} 


\section{INTRODUCTION}

Global aquaculture fish production has increased significantly over the past few decades. In order to increase the fish production, intensive farming method has been widely practiced. Due to this practice, a number of associated factors such as overcrowding, transport, handling, size grading, and poor water quality tend to adversely affect the health of cultured fish. These factors have led to the suppression of the immune system, increasing the susceptibility of fish to infectious diseases as well as substantial economic losses in aquaculture (Anonymous 2014). Further, in the aquatic environment, fishes are constantly exposed to various numbers and types of beneficial and pathogenic microbes and they have evolved an array of strategies and defence mechanisms to prevent the invasion of pathogens. Fish have less developed and slower immune responses compared to other higher vertebrate animals (Manning 1998). Activation of the adaptive immune system requires specific receptor selection, cellular proliferation, and protein synthesis, and all of these are limited by temperature (Harding and Neefjes 2005, Huttenhuis et al. 2005, Randelli et al. 2008). For example, salmonids require 4-6 weeks, while Atlantic cod, Gadus morhua Linnaeus, 1758 needs $10-12$ weeks to exhibit the specific immune responses (Ellis 2001a, Magnadóttir et al. 2001). Therefore, fish are likely to rely highly on their innate immune mechanisms. Several specific and innate immune components have been identified and characterized in different fish species. The major innate immune components include the mucus layer on the skin, gills and gastrointestinal tract, phagocytes, non-specific cytotoxic cells (Evans et al. 2001, Neumann et al. 2001), as well as epithelial and dendritic cells (Dalmo et al. 1996, Ganassin and Bols 1996). Among these, fish mucus is considered a primary and a key component of fish immune system (Ingram 1980). The epidermal mucus is produced primarily by epidermal goblet or mucus cells and is composed mainly of water and gel-forming macromolecules, including mucins and other glycoproteins (Shephard 1993). The mucus layer covers the external surface of fish and reduces the body friction against water and thus protects it from abrasion and/or injuries. Mucus also performs a number of other formidable functions including disease resistance, respiration, ionic and osmotic regulation, locomotion, reproduction, communication, feeding, and nest building (Ingram 1980, Shephard 1994). The mucus layer is continuously replaced, which prevents stable colonization of potential infectious microorganisms and invasion of parasites (Nagashima et al. 2003). The composition and rate of mucus secretion have been observed to change in response to microbial exposure or to environmental perturbations such as hyperosmolarity and $\mathrm{pH}$ (Ellis, 2001b). Fish mucus contains a variety of biologically active substances and innate immune components including lysozyme (LY), proteases (PR), alkaline phosphatase (AP), esterase (ES), immunoglobulins (IG), complement proteins (CP), lectins (L), C-reactive protein, and various other antibacterial proteins and peptides (Subramanian et al. 2008, Palaksha et al. 2008, Arockiaraj et al. 2012, 2013, 2014, Arasu et al.
2013, 2014). It has been reported that these substances are constitutively expressed in mucus to provide immediate protection to fish from potential pathogens. Therefore, fish mucus is considered one of the important components in first-line defence against infectious pathogens.

LY - a bacteriolytic enzyme called N-acetylmuramide glycanohydrolase or muramidase - has been identified in a diverse range of organisms including fish (Alexander and Ingram 1992). LY tends to hydrolyse the chemical bond, $\beta$-glycosidic linkage between $\mathrm{N}$-acetylmuramic acid and $\mathrm{N}$-acetyl glucosamine in the peptidoglycan layer of bacterial cell wall and bind polymers of $\mathrm{N}$-acetyl glucosamine (Arnheim and Wilson 1967). Fish LY has been shown to kill both Gram-positive and Gram-negative bacteria (Jollès and Jollès 1984, Grinde 1989). Enhanced levels of LY have been found in infected and injured fish (Fast et al. 2002, Ross et al. 2000). AP has been demonstrated as a potential stress indicator in the epidermal mucus of Atlantic salmon, Salmo salar Linnaeus, 1758 (see Ross et al. 2000). It is also thought to play a protective role in the initial stage of wound healing in fish and it is known as an antibacterial agent because of its hydrolytic activity (Iger and Abraham 1990, 1997). The level of AP has been shown to be higher in the epidermal mucus of infected fish (Ross et al. 2000, Fast et al. 2002). ES is a hydrolytic enzyme that may act individually or in conjunction with other immune substances in the mucus in resisting pathogens or in wound healing (Palaksha et al. 2008). Fish mucus also contains a variety of PR, which have a significant role in innate immune mechanisms (Subramanian et al. 2007, Palaksha et al. 2008). PR cleaves bacterial proteins and thus directly damaging the pathogen (Ingram 1980). Fish mucus has been found to have metallo-, serine-, cysteine-, and aspartic proteases (Cho et al. 2002, Fast et al. 2002). They also function indirectly by activating and enhancing the production of various immunological components such as complement, immunoglobulin and antimicrobial peptides (Yoshikawa et al. 2001, Cho et al. 2002). LY, AP, and ES with potential immunological functions have been reported from the skin mucus of different species of fish (Subramanian et al. 2007, Palaksha et al. 2008).

To the best of our knowledge, limited studies have been attempted on the innate immune components of the epidermal mucus of Malaysian freshwater fish species. Hence, the presently reported study was aimed to investigate the innate immune components in the epidermal mucus of six commercially important freshwater fish species such as: African catfish, Clarias gariepinus (Burchell, 1822); Indonesian snakehead, Channa micropeltes (Cuvier, 1831); striped snakehead, Channa striatus (Bloch, 1793); marble goby, Oxyeleotris marmorata (Bleeker, 1852); Nile tilapia, Oreochromis niloticus (Linnaeus, 1758); and Asian redtail catfish, Hemibagrus nemurus (Valenciennes, 1840). This study provided a good insight into the innate immune components of mucus, which is imperative for the better understanding of the innate immune mechanisms in fish. 


\section{MATERIALS AND METHODS}

Collection and maintenance of fish. Mucus samples were obtained from Clarias gariepinus, Channa micropeltes, Channa striatus, Oxyeleotris marmorata, Oreochromis niloticus, and Hemibagrus nemurus. All the fishes were obtained from a local fish farm at Sungai Petani, Kedah Darul Aman, Malaysia. The collected fishes were maintained in aerated aquaria at a laboratory of the AIMST University. The fishes were acclimatized separately in circular, $500 \mathrm{~L}$, cement tanks at a stocking density of 10 fish per tank with a water temperature of $28.8 \pm 0.56^{\circ} \mathrm{C}$ and $\mathrm{pH}$ of $6.7 \pm 0.13$. The African catfish, tilapia, and redtail catfish were fed $a d$ libitum with commercial pellet diet twice a day whereas, marble goby, striped snakehead, and Indonesian snakehead were fed with trash fishes (Rasbora spp.). The mean ( \pm standard deviation) body weight of fish was recorded to be $107 \pm 18,640 \pm 168,320 \pm 154,145 \pm 48,116 \pm 50$, and $515 \pm 58 \mathrm{~g}$ for African catfish, Indonesian snakehead, striped snakehead, marble goby, tilapia, and redtail catfish, respectively. The uneaten feed particles were siphoned out from the fish tanks and 50\% water was replaced daily.

Mucus collection and extraction. Mucus was collected following the method of Ross et al. (2000). Only healthy fishes were chosen for mucus collection and fishes with lesions were discarded. Mucus was obtained from 10 individuals of each species. All these fishes were starved for $24 \mathrm{~h}$ before mucus collection, and they were anaesthetized with a sub-lethal dose of $100 \mathrm{mg} \cdot \mathrm{L}^{-1}$ of MS-222 (tricaine methanesulphonate, Sigma, USA). The fishes were transferred individually into a sterile polyethylene bag followed by addition of 5 to $10 \mathrm{~mL}$ of $50 \mathrm{mM} \mathrm{NaCl}$ into the bag immediately. The fish was first gently moved back and forth inside the bag for 3 to 5 min to slough off the mucus and then the used fish was released into the tanks. The collected mucus samples from individual fish species were pooled and split into three replicates per fish species. The pooled mucus samples were stored in $50 \mathrm{~mL}$ sterile Falcon ${ }^{\circledR}$ tube. Then mucus samples were centrifuged at 1500 $\times g^{*}$ (Beckman Coulter, Microfuge 22R Centrifuge) for 10 min at $4^{\circ} \mathrm{C}$. The pellet was discarded and the supernatant was freeze dried (Freeze Dryer SuperModulyo ${ }^{\circledR}$-based High Capacity System) and stored at $-80^{\circ} \mathrm{C}$ until further analysis.

SDS-PAGE analysis. The protein concentration of freeze dried mucus samples were determined based on the method of Bradford (1976) using bovine serum albumin as the standard. The protein profile of epidermal mucus was examined using sodium dodecyl sulphate-polyacrylamide gel electrophoresis (SDS-PAGE) according to Laemmli (1970). Protein samples (20 $\mu \mathrm{g}$ total protein) were diluted $1: 1$ with sample buffer $[4 \%(\mathrm{w} / \mathrm{v}) \mathrm{SDS}, 50 \mathrm{mM}$ Tris- $\mathrm{HCl}$, $2 \%$ mercaptoethanol (v/v), 12\% (v/v) glycerol, and $0.5 \%$ (w/v) bromophenol blue adjusted with $\mathrm{HCl}$ to $\mathrm{pH}$ 6.8] and loaded onto a separating gel of $15 \%$ acrylamide with a $4 \%$ stacking gel. The gel was run in a Bio-Rad electrophoresis apparatus for $4 \mathrm{~h}$ at $150 \mathrm{~V}$. The gel was then stained with Coomassie Brilliant Blue and the protein banding profiles were compared with standard markers (Spectra multicolor High Range Protein Ladder, Fermentas).

Enzyme activity assay. Prior to enzymatic assay, the frozen mucus samples were reconstituted in $2 \mathrm{~mL}$ of the respective enzyme assay buffers and centrifuged (Avanti $\mathrm{J}-26$ XPI, Beckman Coulter) at $9300 \times g$ for $2 \mathrm{~min}$ at $4^{\circ} \mathrm{C}$. Fifty $\mu \mathrm{L}$ of the supernatant was then used for each of the enzyme assay. Prior to start the assay, protein concentration of the supernatant mucus was determined based on Bradford (1976) method. Then, the protein concentration for each mucus sample was determined to calculate for specific activity of the respective enzyme assays. The absorbance for each assay was read using microplate reader (Tecan Infinite M 200 Pro). The entire enzymatic assay was conducted three times for each fish species mucus samples.

The rate of LY activity was determined by turbidimetric method as described by Subramanian et al. (2007). Fifty $\mu \mathrm{L}$ of fish mucus sample in $40 \mathrm{mM}$ sodium phosphate buffer ( $\mathrm{pH}$ 6.5), was transferred to a 96-well plate and incubated at $30^{\circ} \mathrm{C}$ for $15 \mathrm{~min}$. Fifty $\mathrm{mL}$ of lyophilised Micrococcus lysodeikticus substrate $\left(0.3 \mathrm{mg} \mathrm{mL}^{-1}\right.$ in 40 $\mathrm{mM}$ sodium phosphate buffer, $\mathrm{pH} 6.5$, Sigma) were then added and the absorbance was measured continuously for $60 \mathrm{~min}$ at $30^{\circ} \mathrm{C}$. One unit of activity was defined as the amount of enzyme that catalysed a decrease in absorbance at $450 \mathrm{~nm}$ per $0.001 \mathrm{~min}$.

AP assay was conducted following the method of Subramanian et al. (2008) with slight modifications. AP activity was determined by incubating $160 \mu \mathrm{L}$ of mucus reconstituted in $100 \mathrm{mM}$ ammonium bicarbonate and 1 $\mathrm{mM} \mathrm{MgCl}(\mathrm{pH} 7.8)$ at $30^{\circ} \mathrm{C}$ for $15 \mathrm{~min}$. Then, $160 \mu \mathrm{L}$ of 4 $\mathrm{mM}$ p-nitrophenol phosphate substrate was added and the absorbance was measured at $405 \mathrm{~nm}$ over a period of 60 $\min$ at $30^{\circ} \mathrm{C}$. The enzyme activity measured by one unit (U) of activity was defined as the amount of enzyme required to release $1 \mu \mathrm{mol}$ of $\mathrm{p}$-nitrophenol product in $1 \mathrm{~min}$.

ES activity assay was conducted following the method of Palaksha et al. (2007). ES activity was determined continuously over 2-3 h at $405 \mathrm{~nm}$ using p-nitrophenyl myristate substrate (Sigma, USA). An equal volume of mucus sample was incubated with $0.4 \mathrm{mM}$ p-nitrophenyl myristate substrate in $100 \mathrm{mM}$ ammonium bicarbonate buffer containing $1 \%$ Triton $\mathrm{X}-100(\mathrm{pH} 7.8)$ at $30^{\circ} \mathrm{C}$. The enzyme activity measured by one unit (U) of activity was defined as the amount of enzyme required to release $1 \mu \mathrm{mol}$ of p-nitrophenyl myristate product in $1 \mathrm{~min}$.

PR activity was determined using azocasein hydrolysis assay, following the method described by Subramanian et al. (2007) with slight modifications. The assay was conducted by incubating $100 \mu \mathrm{L}$ of the mucus sample in $100 \mathrm{mM}$ ammonium bicarbonate $(\mathrm{pH}$ 7.8) with $100 \mu \mathrm{L}$ azocasein substrate in the same buffer for $19 \mathrm{~h}$ at $30^{\circ} \mathrm{C}$. The reaction was stopped by adding $400 \mu \mathrm{L}$ of $20 \%(\mathrm{w} / \mathrm{v})$ trichloroacetic acid followed by a 5 min centrifugation at $15400 \times g$. Equal volumes $(100 \mu \mathrm{L})$ of the resultant supernatant and $0.5 \mathrm{M} \mathrm{NaOH}$ were added to a 96-well plate and the absorbance was measured at $405 \mathrm{~nm}$. The PR activity 
was measured as the increase in the absorbance values at $450 \mathrm{~nm}$ on a microplate reader (Tecan, Infinite M 200 Pro). Zymography and reverse zymography. For zymography assay (Firth et al. 2000, Subramanian et al. 2008), $50 \mathrm{~mL}$ of freeze dried mucus samples were dissolved in distilled water and sample buffer $[10 \%(\mathrm{w} / \mathrm{v})$ sodium dodecyl sulphate (SDS), $0.5 \mathrm{mM}$ Tris- $\mathrm{HCl}, \mathrm{pH} 6.8$, and $10 \%$ $(\mathrm{v} / \mathrm{v})$ glycerol] in a ratio of $1: 4$ to obtain a final protein concentration of $0.5 \mu \mathrm{g} \cdot \mu \mathrm{L}^{-1}$. Ten $\mu \mathrm{L}$ of the mucus sample was then loaded onto a $12 \%$ SDS polyacrylamide gel containing $0.1 \%(\mathrm{w} / \mathrm{v})$ gelatine and electrophoresed (BioRad electrophoresis apparatus at $150 \mathrm{~V}$ ) at $4^{\circ} \mathrm{C}$ for $1 \mathrm{~h}$. Upon completion, the gel was washed three times with $50 \mathrm{mM}$ Tris- $\mathrm{HCl}(\mathrm{pH} 7.5), 2.5 \%(\mathrm{w} / \mathrm{v})$ Triton $\mathrm{X}-100$, and $0.02 \% \mathrm{NaN}_{3}$ and incubated at $30^{\circ} \mathrm{C}$ for $19 \mathrm{~h}$ in $25 \mathrm{mM}$ Tris- $\mathrm{HCl}$ (pH 7.5), 2.5\% (w/v) Triton X-100, $20 \mathrm{mM}$ $\mathrm{MgCl}_{2}, 5 \mathrm{mM} \mathrm{CaCl}_{2}$, and $0.02 \% \mathrm{NaN}_{3}$. After incubation, the gel was stained with Amido Black stain in $\mathrm{MeOH}$ : $\mathrm{H}_{2} \mathrm{O}: \mathrm{AcOH}(40: 50: 10)$ for $45 \mathrm{~min}$ and destained with $\mathrm{MeOH}: \mathrm{H}_{2} \mathrm{O}: \mathrm{AcOH}(40: 50: 10)$ until the desired contrast was obtained. The gel was immediately scanned using Gel-Doc XR System (Biorad Laboratories). The effect of various inhibitors on PR activity was determined by adding $5 \mathrm{mM}$ p-aminobenzamidine (Sigma, USA), $5 \mathrm{mM}$ EDTA (HmbG Chemicals), $5 \mathrm{mM}$ o-phenanthroline (R \& $\mathrm{M}$ Chemicals), and $5 \mathrm{mM} \alpha$-iodoacetamide (Alfa Aesar, England) specific inhibitors during the incubation step in the azocasein hydrolysis assay and zymography analysis.

Statistical analysis. The data obtained from analysis of protein content and enzyme activity of different fish mucus were analysed using one-way analysis of variance (ANOVA) and significant differences among the means were compared using Duncan's multiple range test (DMRT) on SPSS (ver. 11). Significance was tested at 5\% level. All values shown in this experiment are mean \pm standard deviation $(\mathrm{SD})$.

\section{RESULTS}

SDS-PAGE analysis. The protein content of the mucus of six experimental freshwater fish species are given in Table 1 . The highest protein content $\left(0.5 \pm 0.009 \mu \mathrm{g} \cdot \mu \mathrm{L}^{-1}\right)$ was recorded in tilapia compared to other fish species. The protein content in epidermal mucus was varying among the fish species. SDS-PAGE protein profiles of six fish species are shown in Fig. 1. Electrophoretic comparison of the mucus proteins revealed the differences in the intensity of several protein bands and also demonstrated the variation in expression of similar proteins among fishes. Protein profile of mucus was also varying from species to species, showing the protein bands ranged between 40 $\mathrm{kDa}$ and $300 \mathrm{kDa}$.

Enzyme activity assay. The specific enzyme activities of mucus of six fish species are presented in Table 1. The results confirmed the presence of LY, AP, ES, and PR in the mucus of all the fish species and also a significant amount of variations was noticed in the levels of enzyme activities among the fishes. Significantly $(P<0.05)$ highest specific activity of LY and AP (15.77 and $18.96 \mathrm{U} \cdot \mathrm{mg}^{-1}$ protein) were observed in Channa striatus followed by Clarias gariepinus mucus. The mucus of $C$. gariepinus showed the highest ES activity $\left(16.67 \mathrm{U} \cdot \mathrm{mg}^{-1}\right.$ protein) followed by $C$. striatus. A wide variation of enzyme activities was noticed between species of same genus such as $C$. striatus and Channa micropeltes. Azocasein hydrolysis assay was used to determine the PR activity and showed significantly highest PR level in Hemibagrus nemurus $\left(1630 \mathrm{U} \cdot \mathrm{mg}^{-1}\right.$ protein) followed by $C$. gariepinus $\left(1596.4 \mathrm{U} \cdot \mathrm{mg}^{-1}\right.$ protein) when compared to other fish species. However, statistically no variation was observed in the protease activity between $H$. nemurus and $C$. gariepinus mucus. Despite, C. striatus and C. micropeltes belong to the genus Channa (Channidae), the mucus of $C$. striatus showed 3 times more ES activity than C. micropeltes mucus and C. micropeltes showed 6.5 times more PR activity than $C$. striatus.

Specific inhibitors were added to the azocasein hydrolysis assay to evaluate the PR activity among the fish species and the results are presented in Table 2. The PR inhibition values were calculated as a percent inhibition of the total $(100 \%)$. In the presently reported study, all the PR inhibitors were found to inhibit the specific classes of PR in all the fish species examined. The p-aminobenzamidine inhibitor reduced the PR activities

Table 1

Comparison of protein content and enzyme activities of Clarias gariepinus, Channa micropeltes, Channa striatus, Oxyeleotris marmorata, Oreochromis niloticus, and Hemibagrus nemurus

\begin{tabular}{lccccc}
\hline \multicolumn{1}{c}{ Fish species } & $\begin{array}{c}\text { Protein content } \\
{\left[\mu \mathrm{g} \cdot \mu \mathrm{L}^{-1}\right]}\end{array}$ & $\begin{array}{c}\text { Lysozyme activity } \\
{\left[\mathrm{U} \cdot \mathrm{mg}^{-1} \text { protein }\right]}\end{array}$ & $\begin{array}{c}\text { Alkaline phosphatase } \\
{\left[\mathrm{U} \cdot \mathrm{mg}^{-1} \text { protein }\right]}\end{array}$ & $\begin{array}{c}\text { Esterase activity } \\
{\left[\mathrm{U} \cdot \mathrm{mg}^{-1} \text { protein }\right]}\end{array}$ & $\begin{array}{c}\text { Protease } \\
{\left[\mathrm{U} \cdot \mathrm{mg}^{-1} \text { protein }\right]}\end{array}$ \\
\hline Clarias gariepinus & $0.25 \pm 0.027^{\mathrm{b}}$ & $13.67 \pm 2.82^{\mathrm{a}}$ & $15.06 \pm 2.37^{\mathrm{a}}$ & $16.67 \pm 8.36^{\mathrm{a}}$ & $1596 \pm 94^{\mathrm{a}}$ \\
Channa micropeltes & $0.43 \pm 0.145^{\mathrm{a}}$ & $2.39 \pm 0.92^{\mathrm{c}}$ & $9.36 \pm 1.16^{\mathrm{b}}$ & $2.91 \pm 1.66^{\mathrm{b}}$ & $1123 \pm 133^{\mathrm{b}}$ \\
Channa striatus & $0.41 \pm 0.008^{\mathrm{a}}$ & $15.77 \pm 1.25^{\mathrm{a}}$ & $18.96 \pm 6.68^{\mathrm{a}}$ & $10.65 \pm 5.84^{\mathrm{a}, \mathrm{b}}$ & $171 \pm 20^{\mathrm{c}}$ \\
Oxyeleotris marmorata & $0.28 \pm 0.004^{\mathrm{b}}$ & $8.13 \pm 2.57^{\mathrm{b}}$ & $5.12 \pm 0.19^{\mathrm{b}}$ & $2.33 \pm 1.06^{\mathrm{b}}$ & $226 \pm 81^{\mathrm{c}}$ \\
Oreochromis niloticus & $0.50 \pm 0.009^{\mathrm{a}}$ & $4.02 \pm 0.87^{\mathrm{c}}$ & $8.66 \pm 1.15^{\mathrm{b}}$ & $2.58 \pm 0.84^{\mathrm{b}}$ & $131 \pm 8^{\mathrm{c}}$ \\
Hemibagrus nemurus & $0.42 \pm 0.01^{\mathrm{a}}$ & $3.06 \pm 1.22^{\mathrm{c}}$ & $6.33 \pm 0.98^{\mathrm{b}}$ & $4.88 \pm 3.70^{\mathrm{b}}$ & $1630 \pm 104^{\mathrm{a}}$ \\
\hline
\end{tabular}

Each value is the mean and standard deviation of three replicates; Values followed by a different superscript letter in the same column are significantly different $(P<0.05)$. 


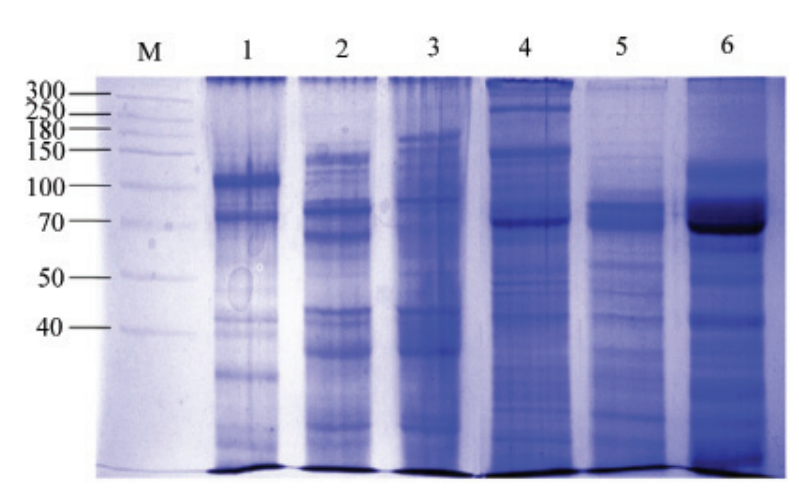

Fig. 1. SDS-PAGE showing the protein profile of mucus samples of six freshwater fish species; $\mathrm{M}=$ marker of molecular mass [kDa], $1=$ Clarias gariepinus, $2=$ Channa micropeltes, $3=$ Channa striatus, $4=$ Oxyeleotris marmorata, 5 = Oreochromis niloticus, $6=$ Hemibagrus nemurus

by 45.45-94.65 percentage points in all the fishes and showed the highest percentage of PR inhibition (94.65 percentage points) in Hemibagrus nemurus mucus followed by Channa micropeltes (87.01 percentage points) and Clarias gariepinus (73.32 percentage points), and the least (45.45 percentage points) in Oxyeleotris marmorata. Another serine protease inhibitor, PMSF showed relatively highest inhibitory activity ( 99.87 percentage points) in Oxyeleotris marmorata followed by C. gariepinus mucus (97.15 percentage points) and the lowest (32.84 percentage points) in Oreochromis niloticus mucus. The serine inhibitors, p-aminobenzamidine and PMSF showed inhibition levels of 32-48 percentage points in O. niloticus and 49-54 percentage points in Channa striatus mucus. These results revealed the presence of low levels of serine proteases in O. niloticus and C. striatus.

The cysteine protease inhibitor, $\alpha$-iodoacetamide reduced the mucus protease levels in all the fish species and showed highest inhibition (87.57 percentage points) in Channa micropeltes followed by Oxyeleotris marmorata (81.82 percentage points). The lowest inhibition (3.89 percentage points) was observed for Clarias gariepinus. The metalloprotease inhibitor, o-phenanthroline, showed highest inhibition (94.55 percentage points) in $O$. marmorata mucus and the lowest (12.7 percentage points) in C. gariepinus. Another metalloprotease inhibitor, EDTA highly reduced the mucus protease activities by 90-94 percentage points in O. marmorata, C. micropeltes, and Hemibagrus nemurus, whereas it showed minimal inhibition in C. gariepinus and Oreochromis niloticus. This study revealed that the highest levels of serine proteases were present in the mucus of $H$. nemurus and $C$. gariepinus compared to cysteine and metalloproteases. In contrast, $C$. micropeltes and $O$. marmorata had similar levels of serine proteases, cysteine and metalloproteases.

Zymography and reverse zymography. Protease zymography was used to elucidate the intensity of protease activities in different fish mucus samples and the results are shown in Fig. 2. The results indicated that a low molecular mass protease of $12-33 \mathrm{kDa}$ was observed in all the fish species examined except marble goby mucus, where bands were visible only from $43 \mathrm{kDa}$ and above. African catfish mucus showed highly variable protease bands ranging from 31.48 to $260 \mathrm{kDa}$. In Indonesian snakehead, less intense protease bands were visible at 33.4 and $44.06 \mathrm{kDa}$ and more intense protease bands at medium and higher molecular mass starting from $44.06 \mathrm{kDa}$ (lane 2). The mucus of striped snakehead showed few less intense bands between 12.73 and $40 \mathrm{kDa}$ and medium to high molecular mass bands in the range of $42.20-140 \mathrm{kDa}$ (lane 3). In marble goby, mucus protease bands were highly visible in the range of $43.11-120 \mathrm{kDa}$ (lane 4). In tilapia, a less intense band at $15.56 \mathrm{kDa}$ and medium to high molecular mass protease bands in the range of 42.66-260 $\mathrm{kDa}$ (lane 5) were observed. The mucus of redtail catfish showed low to high molecular mass protease bands in the range of 23.87-260 kDa (lane 6). Several low and medium molecular mass protease bands between $36-60 \mathrm{kDa}$ were observed in all the fish species. A notable variation in protease activity was observed in the two species of genus, Channa. The striped snakehead had more intense protease bands in the range of 42.20-140 kDa which were not observed in the mucus of Indonesian snakehead (lanes 2 and 3 ).

The effect of various inhibitors on protease activities were determined by adding specific inhibitors such as p-aminobenzamidine, PMSF, $\alpha$-iodoacetamide, o-phenanthroline and EDTA to zymography gels and the results are presented in Figs. 3-7. Addition of p-aminobenzamidine to zymography gel inhibited the majority of the low and high molecular mass proteases in Indonesian snakehead, marble goby, and tilapia (Fig. 3, lanes 2, 4, and 5). The p-aminobenzamidine did not inhibit high molecular mass proteases of African catfish, striped snakehead and redtail catfish. A single intense low molecular mass protease band of approximately $42.79 \mathrm{kDa}$ was visible in African catfish and $50-70 \mathrm{kDa}$ was observed in the mucus of Indonesian snakehead (lanes 1 and 2). In striped snakehead, a clear band of $38.82 \mathrm{kDa}$ protease was observed when incubated with p-aminobenzamidine (lane 3). Clear and highest protease inhibition with $\mathrm{p}$-aminobenzamidine was observed in marble goby and tilapia compared to other fish species examined (lane 4 and 5). Only a single intense medium molecular mass protease band of approximately $68.78 \mathrm{kDa}$ in tilapia was observed (lane 5). PMSF is a serine protease inhibitor and the activity is quite similar to p-aminobenzamidine. However, the proteases with a molecular mass above $50 \mathrm{kDa}$ exhibited less inhibition in African catfish, Indonesian snakehead, striped snakehead, and tilapia mucus (Fig. 4). All the proteases were inhibited when marble goby mucus treated with PMSF (lane 4). The majority of the proteases smaller than $50 \mathrm{kDa}$ were inhibited in all the fishes except a faint band was observed between 30 and $40 \mathrm{kDa}$ in redtail catfish (lane 6). The cysteine protease inhibitor, $\alpha$-iodoacetamide was found to inhibit low molecular mass proteases in all the fishes. A slight inhibition was noticed in the high molecular mass proteases of Indonesian snakehead and marble goby (Fig. 5 , lanes 2 and 4). No inhibition was observed in medi- 
Table 2

Effect of specific protease inhibitors on protease activity in the mucus of Clarias gariepinus, Channa micropeltes, Channa striatus, Oxyeleotris marmorata, Oreochromis niloticus, and Hemibagrus nemurus using the azocasein hydrolysis assay

\begin{tabular}{lcrrrr}
\hline \multirow{2}{*}{\multicolumn{1}{c}{ Fish species }} & \multicolumn{5}{c}{ Inhibitor } \\
\cline { 2 - 6 } & \multicolumn{1}{c}{ p-aminobenzamidine } & \multicolumn{1}{c}{ PMSF } & \multicolumn{1}{c}{$\alpha$-iodoacetamide } & \multicolumn{1}{c}{ o-phenanthroline } & EDTA \\
\hline Clarias gariepinus & $73.32 \pm 0.51^{\mathrm{c}}$ & $97.15 \pm 0.13^{\mathrm{a}}$ & $3.89 \pm 0.38^{\mathrm{e}}$ & $12.7 \pm 1.60^{\mathrm{e}}$ & $28.5 \pm 0.43^{\mathrm{d}}$ \\
Channa micropeltes & $87.01 \pm 0.79^{\mathrm{b}}$ & $83.6 \pm 0.40^{\mathrm{c}}$ & $87.57 \pm 0.40^{\mathrm{a}}$ & $88.14 \pm 1.38^{\mathrm{a}}$ & $90.96 \pm 0.40^{\mathrm{b}}$ \\
Channa striatus & $49.18 \pm 2.37^{\mathrm{d}}$ & $54.12 \pm 5.16^{\mathrm{d}}$ & $59.05 \pm 2.39^{\mathrm{c}}$ & $65.58 \pm 5.33^{\mathrm{b}}$ & $52.46 \pm 0.90^{\mathrm{c}}$ \\
Oxyeleotris marmorata & $45.45 \pm 1.73^{\mathrm{e}}$ & $99.87 \pm 0.07^{\mathrm{a}}$ & $81.82 \pm 0.99^{\mathrm{b}}$ & $94.55 \pm 6.75^{\mathrm{a}}$ & $90.91 \pm 0.78^{\mathrm{b}}$ \\
Oreochromis niloticus & $48.4 \pm 2.07^{\mathrm{d}}$ & $32.84 \pm 0.77^{\mathrm{e}}$ & $81.43 \pm 0.78^{\mathrm{b}}$ & $54.28 \pm 1.04^{\mathrm{c}}$ & $28.56 \pm 1.56^{\mathrm{d}}$ \\
Hemibagrus nemurus & $94.65 \pm 0.02^{\mathrm{a}}$ & $89.14 \pm 0.49^{\mathrm{b}}$ & $29.82 \pm 0.44^{\mathrm{d}}$ & $43.27 \pm 0.78^{\mathrm{d}}$ & $93.68 \pm 00^{\mathrm{a}}$ \\
\hline
\end{tabular}

Values are expressed as a percent inhibition of the total $(100 \%)$ control protease activity; Each value is the mean and standard deviation of three replicates; Values followed by a different superscript letter in the same column are significantly different $(P<0.05)$.

um and high molecular mass proteases of African catfish, striped snakehead, tilapia, and redtail catfish mucus (Fig. 5 , lanes $1,3,5$, and 6). Inhibition was noticed in the low and medium molecular mass protease bands in all species when a zymography gel was incubated with o-phenanthroline (Fig. 6). A slight inhibition was noticed in high molecular mass protease of Indonesian snakehead and marble goby. High molecular mass proteases were not inhibited by o-phenanthroline in African catfish, striped snakehead and redtail catfish (Fig. 7, lanes 1, 3, and 6). Metalloprotease inhibitor, EDTA was found to inhibit most of the low molecular mass proteases in all the fish species except a few faint bands between 30 and $15 \mathrm{kDa}$ in African catfish, tilapia, and redtail catfish mucus (Fig. 7, lanes 1, 5, and 6).

\section{DISCUSSION}

Fish epidermal mucus being continuously produced and sloughed off from the integumental surface, where it is physically trapping and preventing microbial pathogens from attaching to the epithelium (Sheikhzadeh et al. 2012). The involvement of epidermal mucus enzymes such as lysozyme and proteases in the innate immune mechanism of fish has hitherto been studied (Yano 1996, Aranishi 1999). Several studies have been conducted to explore the antimicrobial activity, immune components, and hydrolytic enzymes in the mucus of different fish species (Yano 1996, Subramanian et al. 2007, Palaksha et al. 2008). However to date, no information is available specifically on the protein profile and innate immune components of mucus of the six fish species that were examined in this study. A marked variation was observed in the specific activities of hydrolytic enzymes among the fish species and also fish species within the same genus (Channa), indicating their importance in protecting fish against pathogens.

This study demonstrated the variation in protein profiles and their contents in the mucus of the six fish species examined. Several studies reported that the changes in protein content and composition of fish mucus usually occur as a result of several physiological conditions of fish such as maturation, smoltification, and starvation (Fagan et al. 2003). The variation in protein content was observed in epidermal mucus of juvenile and parental discus fish,
Symphysodon spp. (see Chong et al. 2005). In general, epidermal mucus contains water, glycoprotein, secretary proteins, amino acids, lipids, sloughed epithelial cells, and bacteria (Shephard 1994), immunoglobulin, complement, C-reactive proteins, lectins, lysozyme, and haemolysins (Yano 1996).

Skin mucosal lysozyme was found to vary among freshwater fish species. In the presently reported study low levels of lysozyme activity in the epidermal mucus of all the six fish species was noticed compared to the previous studies in different freshwater and marine fish species. Palaksha et al. (2008) found a lysozyme activity of (233.33 U $\cdot \mathrm{mg}^{-1}$ protein) in olive flounder, Paralichthys olivaceus (Temminck et Schlegel, 1846) and (16-124 $\mathrm{U} \cdot \mathrm{mg}^{-1}$ protein) in different freshwater fishes such as: Arctic char, Salvelinus alpinus (Linnaeus, 1758); brook trout, Salvelinus fontinalis (Mitchill, 1814); striped bass, Morone saxatilis (Walbaum, 1792); and koi carp, Cyprinus carpio Linnaeus, 1758; and marine fishes such as: haddock, Melanogrammus aeglefinus (Linnaeus, 1758); Atlantic cod, Gadus morhua; and Atlantic hagfish, Myxine glutinosa Linnaeus, 1758 (see Subramanian et al. 2007). An increased lysozyme activity was observed in seawater fish than freshwater-reared fish species (Subramanian et al. 2007). In contrast, an increased lysozyme activity has been reported in freshwater reared rainbow trout, coho salmon, and Atlantic salmon than seawater-reared fish (Fast et al. 2002). This difference in lysozyme activity could be attributed to the species-specific evolutionary adaptation to different environmental conditions. The variation in enzyme activities is also thought to be related to the thickness of the epidermis and the number of mucus cells (Fast et al. 2002). In the presently reported study, highest lysozyme activity was noticed in striped snakehead and African catfish. Genetically these species are air breathing fish and can thrive in poor water quality conditions, and also produce copious amounts of mucus compared to the other fish species examined in the study, suggesting that the hypothesis on epidermal thickness and enzyme activity could partially apply for African catfish and striped snakehead. The variation in lysozyme activity could also be attributed to several other factors such as 


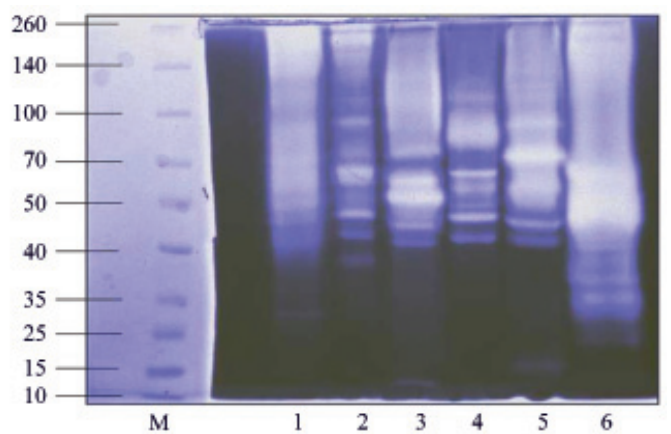

1

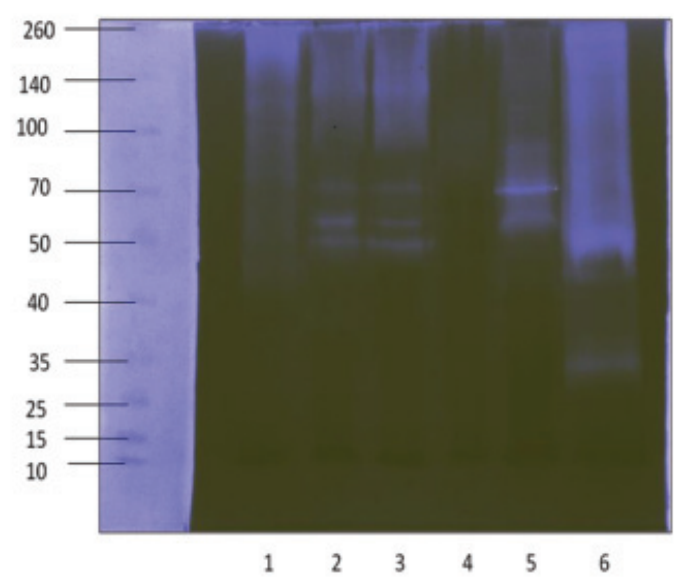

3

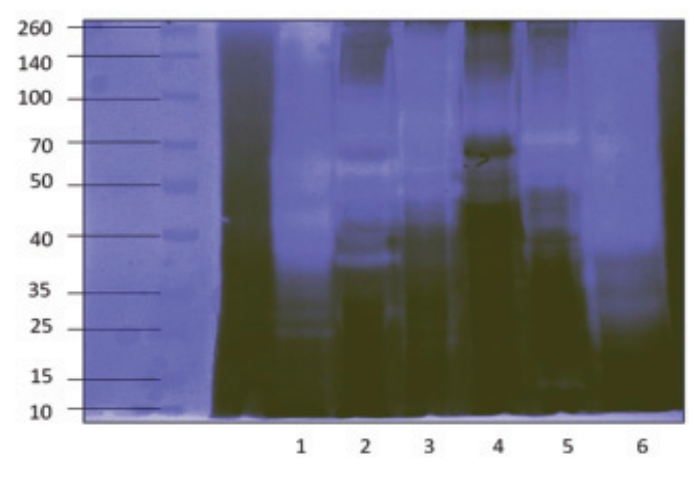

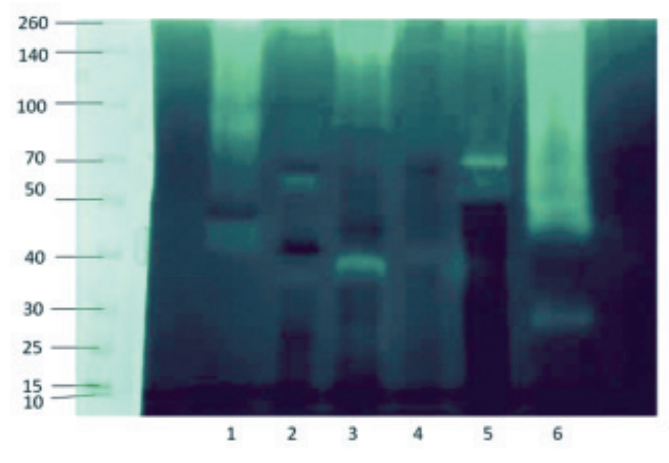

2

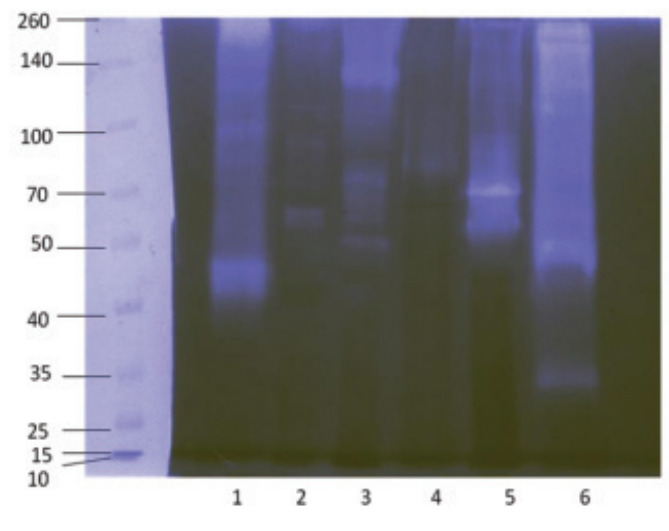

4

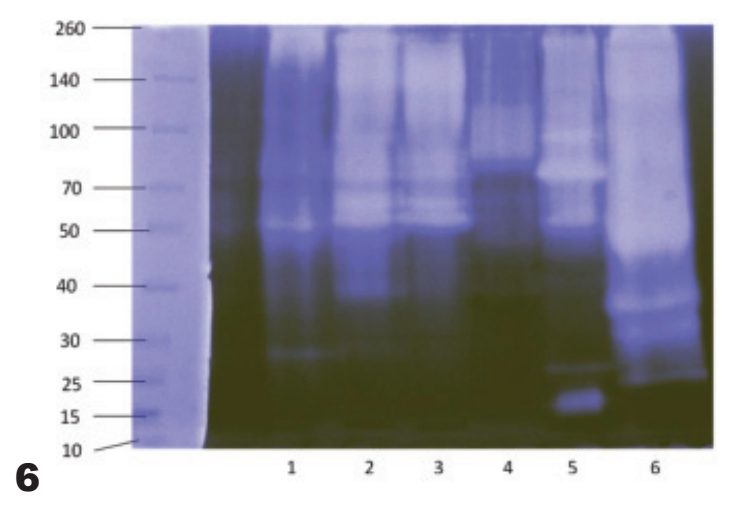

Figs. 2-7. Protease zymography of the mucus of six freshwater fish species $(1=$ Clarias gariepinus, $2=$ Channa micropeltes, 3 = Channa striatus, 4 = Oxyeleotris marmorata, $5=$ Oreochromis niloticus, $6=$ Hemibagrus nemurus); Fig. 2. Incubated without inhibitor; Fig. 3. Iincubated with specific protease inhibitor, p-aminobenzamidine (5 mM); Fig. 4. Incubated with specific protease inhibitor PMSF ( $5 \mathrm{mM})$; Fig. 5. Incubated with specific protease inhibitor $\alpha$-iodoacetamide ( $5 \mathrm{mM}$ ); Fig. 6. Incubated with specific protease inhibitor, o-phenanthroline (5mM); Fig. 7. Incubated with specific protease inhibitor, EDTA $(5 \mathrm{mM}) ; \mathrm{M}=$ marker of broad range molecular mass [kDa]

handling stress, maturity, diet, sex, species variation, and genetic variation (Balfry and Iwama 2004).

In the presently reported study, the alkaline phosphatase activity varied from 6.33 to $18.96 \mathrm{U} \cdot \mathrm{mg}^{-1}$ protein among the fish species. The total alkaline phosphatase activity exhibited in this study was higher than the previous studies by Subramanian et al. (2007) and Palaksha et al. (2008) in the mucus of different freshwater and sea-water fish species. Similar to lysozyme activity, an increased alkaline phosphatase activity was also observed in striped snakehead and African catfish compared to the other fish species. The variations in the alkaline phosphatase activity in different fish species and their precise role in the innate immune mechanisms have yet to be elucidated. Esterase is also a hydrolase enzyme like alkaline phosphatase. The activity of esterase varied from 2.91 to $16.67 \mathrm{U} \cdot \mathrm{mg}^{-1}$ protein in the six fish species. A higher esterase activity was reported in the skin mucus of fish, administered with Ergosan and fed with fermented Saccharomyces cerevisiae (see Sheikhzadeh et al. 2012). The presently reported investigation revealed a comparable and higher esterase activity $\left(16.67 \mathrm{U} \cdot \mathrm{mg}^{-1}\right.$ protein) in African cat- 
fish mucus. Low esterase activity was reported in olive flounder than that observed in this study (Palaksha et al. 2008). The precise role of esterase has not been distinct and it seems likely that it could act either individually or in cooperation with immune mucus substances towards fighting against infection or in wound healing (Palaksha et al. 2008, Sheikhzadeh et al. 2012). A variation in the level of protease activity was observed among the mucus of fish species examined. Comparatively highest level of protease activity was noticed in all the fish species than other mucus enzymes. The protease activity is found to be higher than the previous studies by Subramanian et al. (2007) and Palaksha et al. (2008) in the mucus of different freshwater and sea-water fish species.

The results of the azocasein hydrolysis assay showed the presence of a higher level of serine proteases followed by metalloproteases in the mucus of all the six fish species. The activity of serine protease inhibitors, p-aminobenzamidine and PMSF in all the fish species was found to be similar, whereas variation was noticed only in marble goby fish mucus protease. In marble goby, PMSF showed inhibition by 99.87 percentage points, while p-aminobenzamidine inhibited the protease activity up to 45.45 percentage points. This is probably due to reduced activity of trypsin-like proteases in the marble goby mucus. A similar observation was reported in hagfish mucus, where p-aminobenzamidine exhibited no inhibition at all and the other serine inhibitor, aprotinin, inhibited up to 30 percentage points of the protease activity (Subramanian et al. 2007). Similarly, metalloprotease and o-phenanthroline inhibitors showed low activity (43.27) and EDTA inhibited by 93.68 percentage points the total protease activity in redtail catfish mucus. Similar findings were reported by (Subramanian et al. 2007) in hagfish mucus where o-phenanthroline showed no inhibition and EDTA inhibited by 36 percentage points of the total protease activity. The cysteine protease inhibitor, $\alpha$-iodoacetamide caused higher rate of inhibition in Indonesian snakehead, tilapia, and marble goby mucus protease than other fishes and this suggests that these fishes might have more cysteine proteases.

The presently reported study observed the highest serine proteases in African catfish, Indonesian snakehead, and redtail catfish and metalloproteases in Indonesian snakehead and marble goby and cysteine proteases in Indonesian snakehead, marble goby and tilapia. The role of serine-, metallo-, and cysteine proteases in the innate immune response has hitherto been examined. Highest serine and metalloproteases were noticed in the mucus of Arctic char, brook trout, koi carp, striped bass, haddock, cod, and hagfish (Subramanian et al. 2007). Metalloproteases have been identified in the epidermal mucus of catfish (Cho et al. 2002), coho salmon, Atlantic salmon, and rainbow trout (Fast et al. 2002).

Based on the results of azocasein hydrolysis and zymography, it could be found that there is a wide variability in the types of proteases in fish mucus. This could imply that one or two proteases are inhibited by all the inhibitors, while some of them are not inhibited. In this study, p-aminobenzamidine and PMSF inhibited the most of the medium as well as low molecular mass protease bands of African catfish, redtail catfish, and snakeheads, suggesting trypsin-like proteases are the major proteases in the mucus. Subramanian et al. (2007) reported that p-aminobenzamidine inhibited low molecular mass serine proteases in different fish species. The two metalloprotease inhibitors tested in this study showed different effects on the protease activities; EDTA inhibited the majority of medium molecular mass proteases, while o-phenanthroline inhibited the majority of medium and low molecular mass proteases. This may be due to the presence of calcium-specific metalloproteases as some proteases are inhibited both by EDTA and o-phenanthroline. It further suggests that EDTA is a cation chelator that binds to calcium and iron, while o-phenanthroline mainly targets zinc with a much lower affinity for calcium (Auld 1995, Salvesen and Nagase 2001).

The presently reported study is the first of its kind to confirm the presence of innate components such as lysozyme, alkaline phosphatase, esterase, and proteolytic enzymes in the epidermal mucus of Clarias gariepinus, Clarias micropeltes, Channa striatus, Oxyeleotris marmorata, Oreochromis niloticus, and Hemibagrus nemurus. Conclusively this study showed a significant variation in the relative levels of lysozyme, alkaline phosphatase, esterase, and proteases in the epidermal mucus of the all the fish species. There have been no clear evidences available to explain the variation of enzyme activities in different fishes in a variety of habitats, whether it might occur due to evolutionary or genetic adaptation of these species to environmental factors. A significant observation from our study was the presence of the higher levels of lysozyme and several proteases in the epidermal mucus of African catfish and snakehead fishes. From an evolutionary perspective, these fishes are unique and posses an accessory respiratory organ for respiration as well as can thrive in low dissolved oxygen in water, paddy field and muddy environments, and produce more mucus than other freshwater fishes. To survive in such a harsh environmental condition, the requirement of high levels of these innate immune factors is of prerequisite. In addition, all these immune components in epidermal mucus may play an important role in survival of fish in different environmental conditions.

\section{ACKNOWLEDGEMENTS}

We acknowledge the research support received from King Saud University, Deanship of Scientific Research, Addiriyah Chair for Environmental Studies to complete this study. The authors would also like to thank Dr. Neil Ross (National Research Council Institute for Marine Biosciences, Halifax NS, Canada) for helping the enzyme assays.

\section{REFERENCES}

Alexander J.B., Ingram G.I. 1992. Noncellular nonspecific defence mechanisms of fish. Annual Reviews in Fish Diseases 2: 249-279.

DOI: 10.1016/0959-8030(92)90066-7

Anonymous 2014. The state of world fisheries and aquaculture - opportunities and Challenges. Food and Agriculture Organization of the United Nations, Rome. 
Aranishi F. 1999. Possible role for cathepsins L and B in bacteriolysis by Japanese eel skin. Fish and Shellfish Immunology 8 (1): 61-64.

DOI: $10.1006 /$ fsim.1998.0160

Arasu A., Kumaresan V., Sathyamoorthi A., Chaurasia M.K., Bhatt P., Gnanam A.J., Palanisamy R., Marimuthu K., Pasupuleti M., Arockiaraj J. 2014. Molecular characterization of a novel proto-type antimicrobial protein galectin-1 from striped murrel. Microbiological Research 169 (11): 824-834.

DOI: $10.1016 /$ j.micres.2014.03.005

Arasu A., Kumaresan V., Sathyamoorthi A., Palanisamy R., Prabha N., Bhatt P., Roy A., Thirumalai M.K., Gnanam A.J., Pasupuleti M., Marimuthu K., Arockiaraj J. 2013. Fish lily type lectin-1 contains $\beta$-prism architecture: Immunological characterization. Molecular Immunology 56 (4): 497-506.

DOI: 10.1016/j.molimm.2013.06.020

Arnheim N.jr., Wilson A. 1967. Quantitative immunological comparison of bird lysozymes. Journal of Biological Chemistry 242 (17): 3951-3956.

Arockiaraj J., Gnanam A.J., Dhanaraj M., Ranganath G., Milton J., Singh A., Saravanan M., Marimuthu K., Subha B. 2012. Crustin, a WAP domain containing antimicrobial peptide from freshwater prawn Macrobrachium rosenbergii: Immune characterization. Fish and Shellfish Immunology 34 (1): 109-118. DOI: $10.1016 /$ j.fsi.2012.10.009

Arockiaraj J., Gnanam A.J., Kumaresan V., Palanisamy R., Bhatt P., Thirumalai M.K., Roy A., Pasupuleti M., Marimuthu K. 2013. An unconventional antimicrobial protein histone from freshwater prawn Macrobrachium rosenbergii: Analysis of immune properties. Fish and Shellfish Immunology 35 (5): 1511-1522.

DOI: 10.1016/j.fsi.2013.08.018

Arockiaraj J., Kumaresan V., Bhatt P., Palanisamy R., Gnanam A.J., Pasupuleti M., Marimuthu K., Chaurasia M.K. 2014. A novel single-domain peptide, anti-LPS factor from prawn: Synthesis of peptide, antimicrobial properties and complete molecular characterization. Peptides 53: 79-88.

DOI: $10.1016 /$ j.peptides.2013.11.008

Auld D.S. 1995. Removal and replacement of metal ions in metallopeptidases. Methods in Enzymology 248: 228-242.

DOI: $10.1016 / 0076-6879(95) 48016-1$

Balfry S.K., Iwama G.K. 2004. Observation on the inherent variability of measuring lysozyme activity in coho salmon (Oncorhynchus kisutch). Comparative Biochemistry and Physiology Part B: Biochemistry and Molecular Biology 138 (3): 207-211.

DOI: $10.1016 /$ j.cbpc.2003.12.010

Bradford M.M. 1976. A rapid and sensitive method for the quantification of microgram quantities of proteins utilizing the principle of protein-dye binding. Analytical Biochemistry 72 (1-2): 248-254.

DOI: $10.1016 / 0003-2697(76) 90527-3$
Cho J.H., Park I.Y., Kim H.S., Lee W.T., Kim M.S., Kim S.C. 2002. Cathepsin D produces antimicrobial peptide parasin I from histone $\mathrm{H} 2 \mathrm{~A}$ in the skin mucosa of fish. FASEB Journal 16 (3): 429-431.

DOI: 10.1096/fj.01-0736fje

Chong K., Tham S.Y., Foo J., Lam T.J., Chong A. 2005. Characterisation of proteins in epidermal mucus of discus fish (Symphysodon spp.) during parental phase. Aquaculture 249 (1-4): 469-476.

DOI: $10.1016 /$ j.aquaculture.2005.02.045

Dalmo R.A., Ingebrigsten K., Sveinbjørnsson B., Seljelid R. 1996. Accumulation of immunomodulatory laminaran $(\beta(1,3)$-D-glucan) in the heart, spleen and kidney of Atlantic cod, Gadus morhua L. Journal of Fish Diseases 19 (2): 129-136.

DOI: 10.1111/j.1365-2761.1996.tb00691.x

Ellis A.E. 2001a. Innate host defense mechanisms of fish against viruses and bacteria. Developmental and Comparative Immunology 25 (8-9): 827-839.

DOI: $10.1016 / \mathrm{S} 0145-305 \mathrm{X}(01) 00038-6$

Ellis A.E. 2001b. The immunology of teleosts. Pp. 133150. In: Roberts R.J. (ed.) Fish pathology. 3rd edn. Elsevier, Amsterdam, The Netherlands.

Evans D.L., Leary J.H., Jaso-Friedmann L. 2001. Nonspecific cytotoxic cells and innate immunity: Regulation by programmed cell death. Developmental and Comparative Immunology 25 (8-9): 791-805.

DOI: $10.1016 / \mathrm{S} 0145-305 \mathrm{X}(01) 00036-2$

Fagan M.S., O'Byrne-Ring N., Ryan R., Cotter D., Whelan K., Mac Evilly U. 2003. A biochemical study of mucus lysozyme, proteins and plasma thyroxine of Atlantic salmon (Salmo salar) during smoltification. Aquaculture 222 (1-4): 287-300. DOI: $10.1016 / \mathrm{S} 0044-8486(03) 00128-5$

Fast M.D., Sims D.E., Burka J.F., Mustafa A., Ross N.W. 2002. Skin morphology and humoral non-specific defence parameters of mucus and plasma in rainbow trout, coho and Atlantic salmon. Comparative Biochemistry and Physiology Part A: Molecular and Integrative Phusiology 132 (3): 645-657. DOI: 10.1016/S1095-6433(02)00109-5

Firth K.J., Johnson S.C., Ross N.W. 2000. Characterization of proteases in the skin mucus of Atlantic salmon (Salmo salar) infected with the salmon louse (Lepeophtheirus salmonis) and in whole-body louse homogenate. Journal of Parasitology 86 (6): 1199-1205. DOI: $10.2307 / 3285000$

Ganassin R.C., Bols N.C. 1996. Development of longterm rainbow trout spleen cultures that are haemopoietic and produce dendritic cells. Fish and Shellfish Immunology 6 (1): 17-34. DOI: $10.1006 /$ fsim. 1996.0003

Grinde B. 1989. Lysozyme from rainbow trout, Salmo gardneri Richardson, as an antibacterial agent against fish pathogens. Journal of Fish Diseases 12 (2): 95-104. DOI: $10.1111 /$ j.1365-2761.1989.tb00281.x

Harding C.V., Neefjes J. 2005. Antigen processing and recognition. Current Opinion in Immunology 17 (1): 55-57. DOI: 10.1016/j.coi.2004.12.007 
Huttenhuis H.B.T., Huising M.O., van der Meulen T., van Oosterhoud C.N., Sánchez N.A., Taverne-Thiele A.J., Stroband H.W.J., Rombout J.H.W.M. 2005. Rag expression identifies B and T cell lymphopoietic tissues during the development of common carp (Cyprinus carpio). Developmental and Comparative Immunology 29 (12): 1033-1047.

DOI: $10.1016 /$ j.dci.2005.03.005

Iger Y., Abraham M. 1990. The process of skin healing in experimentally wounded carp. Journal of Fish Biology 36 (3): 421-437.

DOI: $10.1111 /$ j.1095-8649.1990.tb05622.x

Iger Y., Abraham M. 1997. Rodlet cells in the epidermis of fish exposed to stressors. Tissue and Cell 29 (4): 431-438.

DOI: $10.1016 / \mathrm{S} 0040-8166(97) 80029-8$

Ingram G.I. 1980. Substances involved in the natural resistance of fish to infection-A review. Journal of Fish Biology 16 (1): 23-60.

DOI: $10.1111 / \mathrm{j} .1095-8649.1980 . t b 03685 . x$

Jollès P., Jollès J. 1984. What's new in lysozyme research? Always a model system, today as yesterday. Molecular and Cellular Biochemistry 63 (2): 165-189. DOI: $10.1007 / \mathrm{BF} 00285225$

Laemmli U.K. 1970. Cleavage of structural proteins during the assembly of the head of bacteriophage T4. Nature 227 (5259): 680-685.

DOI: $10.1038 / 227680 \mathrm{a} 0$

Magnadóttir B., Jonsdóttir H., Helgason S., Björnsson B., Solem ST., Pilström L. 2001. Immune parameters of immunised cod (Gadus morhua L.). Fish and Shellfish Immunology 11 (1): 75-89.

DOI: $10.1006 /$ fsim.2000.0296

Manning M.J. 1998. Immune defence systems. Pp. 180221. In: Blanck K.D., Pickering, A.D. (eds.) Biology of farmed fish. Sheffield Academic Press, Sheffield, UK.

Nagashima Y., Kikuchi N., Shimakura K., Shiomi K. 2003. Purification and characterization of an antibacterial protein in the skin secretion of rockfish Sebastes schlegeli. Comparative Biochemistry and Physiology Part C: Toxicology and Pharmacology 136 (1): 63-71. DOI: $10.1016 / \mathrm{S} 1532-0456(03) 00174-1$

Neumann N.F., Stafford J.L., Barreda D., Ainsworth A.J., Belosevic M. 2001. Antimicrobial mechanisms of fish phagocytes and their role in host defense. Developmental and Comparative Immunology 25 (8-9): 807-825.

DOI: 10.1016/S0145-305X(01)00037-4

Palaksha K.J., Shin G.W., Kim Y.R., Sung T.S. 2008. Evaluation of non-specific immune components from the skin mucus of olive flounder (Paralichthys olivaceus). Fish and Shellfish Immunology 24 (4): 479-488. DOI: 10.1016/j.fsi.2008.01.005
Randelli E., Buonocore, F., Scapigliati G. 2008. Cell markers and determinants in fish immunology. Fish and Shellfish Immunology 25 (4): 326-340.

DOI: 10.1016/j.fsi.2008.03.019

Ross N.W., Firth K.J., Wang A., Burka J.F., Johnson S.C. 2000. Changes in hydrolytic enzyme activities of naïve Atlantic salmon Salmo salar skin mucus due to infection with the salmon louse Lepeophtheirus salmonis and cortisol implantation. Diseases of Aquatic Organisms 41: 43-51.

DOI: $10.3354 /$ dao041043

Salvesen G.S., Nagase H. 2001. Inhibition of proteolytic enzymes. Pp. 105-130. In: Beynon R.J., Bond J.S. (eds.) Proteolytic enzymes: A practical approach. 2nd edn. Oxford University Press, Oxford, UK.

Sheikhzadeh N., Pashaki A.K., Nofouzi K., Heidarieh M., Tayefi-Nasrabadi H. 2012. Effects of dietary Ergosan on cutaneous mucosal immune response in rainbow trout (Oncorhynchus mykiss). Fish and Shellfish Immunology 32 (3): 407-410.

DOI: $10.1016 /$ j.fsi.2011.11.028

Shephard K.L. 1993. Mucus on the epidermis of fish and its influence on drug delivery. Advanced Drug Delivery Reviews 11 (3): 403-417.

DOI: 10.1016/0169-409X(93)90018-Y

Shephard K.L. 1994. Functions for fish mucus. Reviews in Fish Biology and Fisheries 4 (4): 401-429.

DOI: $10.1007 / \mathrm{BF} 00042888$

Subramanian S., MacKinnon S.L., Ross N.W. 2007. A comparative study on innate immune parameters in the epidermal mucus of various fish species. Comparative Biochemistry and Physiology Part B: Biochemistry and Molecular Biology 148 (3): 256-263.

DOI: $10.1016 /$ j.cbpb.2007.06.003

Subramanian S., Ross N.W., MacKinnon S.L. 2008. Comparison of the biochemical composition of normal epidermis mucus and extruded slime of hagfish (Myxine glutinosa L.). Fish and Shellfish Immunology 25 (5): 625-632.

DOI: $10.1016 /$ j.fsi.2008.08.012

Yano T. 1996. The non-specific immune system: Humoral defense. Pp. 105-157. In: Iwama G., Nakanishi T. (eds.) The fish immune system: Organism, pathogen and environment. Academic Press, London, UK.

Yoshikawa T., Imada T., Nakakubo H., Nakamura N., Naito K. 2001. Rat mast cell protease-I enhances immunoglobulin E production by mouse B cells stimulated with interleukin-4. Immunology 104 (3): 333-340.

DOI: $10.1046 / \mathrm{j} .1365-2567.2001 .01320 . \mathrm{x}$

Received: 23 June 2014

Accepted: 1 April 2015

Published electronically: 30 September 2015 